\title{
Infrared Transmittance of Some Calcium Aluminate and Germanate Glasses ${ }^{12}$
}

\author{
Jack M. Florence, ${ }^{3}$ Francis W. Glaze, and Mason H. Black
}

\begin{abstract}
The infrared transmittance of some calcium aluminate and germanate glasses has been measured out to 6 microns. The range of compositions of the calcium aluminate glasses was $\mathrm{CaO}, 26.7$ to 52.0 percent, and $\mathrm{Al}_{2} \mathrm{O}_{3}, 28.2$ to 49.6 percent. Barium oxide, $\mathrm{BeO}, \mathrm{Bi}_{2} \mathrm{O}_{3}$, $\mathrm{La}_{2} \mathrm{O}_{3}, \mathrm{MgO}$, and $\mathrm{PbO}$ were added in varying amounts up to a maximum of 36.0 percent for any one constituent. These calcium aluminate glasses are good infrared transmitters, but show a prominent water absorption band at 2.9 to 3.0 microns. This absorption can be decreased somewhat by means of a dry air treatment of the melt. These glasses have a strong tendency toward devitrification.

Germanium oxide is a good glass-former. Its glasses have about the same infrared transmittance as the calcium aluminate glasses in the absence of oxides such as $\mathrm{SiO}_{2}$ and $\mathrm{BeO}$, which absorb in the 4.5- to 5.5-micron region.
\end{abstract}

\section{Introduction}

The study of the transmittance of infrared energy by glass $[1,2,3]^{4}$ at the National Bureau of Standards has resulted in the preparation of glasses departing from the ordinary glass compositions. The common glass-forming oxides are $\mathrm{B}_{2} \mathrm{O}_{3}, \mathrm{P}_{2} \mathrm{O}_{5}$, and $\mathrm{SiO}_{2}$. Samples of glasses, $2 \mathrm{~mm}$ thick, prepared with $\mathrm{B}_{2} \mathrm{O}_{3}$ and $\mathrm{P}_{2} \mathrm{O}_{5}$ transmit very little infrared energy beyond the water absorption band at $2.9 \mu$. Silica is the best of the ordinary glass-formers as far as the transmittance of infrared energy is concerned. However, silicate glasses in 2-mm thicknesses do not transmit much energy of wavelengths beyond approximately $4.5 \mu$ because of the absorption by $\mathrm{Si}-\mathrm{O}$ bond at $4.45 \mu$. Other compounds considered to be glass-formers are $\mathrm{GeO}_{2}, \mathrm{Al}_{2} \mathrm{O}_{3}$, $\mathrm{BeF}_{2}, \mathrm{Sb}_{2} \mathrm{O}_{3}, \mathrm{~V}_{2} \mathrm{O}_{5}$, and $\mathrm{Bi}_{2} \mathrm{O}_{3}$. Only those compositions which showed promise of being able to produce glass blanks of appreciable size, and which could be melted in platimun, were investigated. They contained $\mathrm{CaO}+\mathrm{Al}_{2} \mathrm{O}_{3}, \mathrm{GeO}_{2}$, or $\mathrm{BeF}_{2}$.

Some $\mathrm{BeF}_{2}$ glasses, similar to those reported by Heyne [4], were prepared free from visible crystallization only by incorporating ammonium acid fluoride in the batch. These glasses were found to be readily attacked by water, as reported by Heyne, hence were given no further consideration.

$\mathrm{GeO}_{2}$ glasses are interesting, but, unfortunately, the cost of germanium is high and the material is in great demand in the electronics field. However, a limited number of compositions were studied.

The glass-forming ability of $\mathrm{Al}_{2} \mathrm{O}_{3}$ has been in controversy since the beginning of the century. The earliest reported aluminate glass was by Shepherd, Rankin, and Wright [5], from the study of the $\mathrm{MgO}-\mathrm{CaO}-\mathrm{Al}_{2} \mathrm{O}_{3}$ system. Bussem and Eitel [6] found that the composition 52.2 percent $\mathrm{Al}_{2} \mathrm{O}_{3}$ and 47.8 percent_ $\mathrm{CaO}$ could be quenched to glass.

1 Presented at the Fifty-Seventh Annual Meetin of the American Ceramic Society, Cincinnati, Ohio, April $27,1955$.

2 This project was supported by the Department of the Navy, Bureau of Ships. 3 Present address, Kimble Glass Co., Toledo, Ohio.

4 Figures in brackets indicate the literature references at the end of this paper.
Stevels [7] and Safford and Silverman [8] regard it as improbable that such a glass could be formed. Further phase-equilibria studies of the calcium aluminates with a third component have indicated the ability of aluminum atoms to assume the fourfold coordination said to be necessary for glass formation [9]. Sun $[9,10]$ has published and patented a series of aluminate and beryllo-aluminate glasses. Sun $[11,12]$ and Stanworth $[12,13]$ published a series of notes on the aluminate glasses. Weyl [14] states that " $\mathrm{Al}_{2} \mathrm{O}_{3}$ can play the role of glass-forming oxide only in combination with $\mathrm{CaO}$, the only example of a pure aluminate glass being the vitreous calcium aluminate."

\section{Preparation of the Glasses}

The procedure for the preparation of the glasses and for the transmittance measurements has been given in previous publications $[1,2]$. During the fining of several of the glasses, dry air was introduced into the bottom of the melt by means of a platinum tube for $2 \mathrm{hr}$. This procedure is referred to, for brevity, as the "dry-air treatment" [3]. With some glasses of low viscosity, this treatment is very effective in removing water vapor and possibly other soluble gases.

Both anhydrous and hydrated alumina, as indicated in table 1, were used in the batches as the source of $\mathrm{Al}_{2} \mathrm{O}_{3}$.

\section{Calcium Aluminate Glasses}

The base glasses for this phase of the work were the low silica eutectic composition from the $\mathrm{CaO}-\mathrm{Al}_{2} \mathrm{O}_{3}-\mathrm{SiO}_{2}$ phase diagram and another glass of very similar composition [15, 16]. Glass C-1458 (fig. 1) is the ternary eutectic composition. The other glass (C-1474, fig. 2) is very similar to one mentioned by Dusing in U. S. Patent No. 2,252,495, covering a series of infrared transmitting glasses. Dusing reports that a glass of composition, $\mathrm{SiO}_{2}, 6.9$ percent, $\mathrm{CaO}, 49.7$ percent, and $\mathrm{Al}_{2} \mathrm{O}_{3}, 43.4$ percent, transmits infrared energy beyond $6 \mu$ for a sample 1 
TABLE 1. Glass compositions

\begin{tabular}{|c|c|c|c|c|c|c|c|c|c|c|c|c|}
\hline \multirow{2}{*}{$\begin{array}{c}\text { Figure } \\
\text { No. }\end{array}$} & \multirow{2}{*}{ Glass No. } & \multicolumn{10}{|c|}{ Composition in weight percent } & \multirow{2}{*}{ Remarks } \\
\hline & & $\mathrm{SiO}_{2}$ & $\mathrm{Al}_{2} \mathrm{O}_{3}$ & $\mathrm{CaO}$ & $\mathrm{MgO}$ & $\mathrm{GeO}_{2}$ & $\mathrm{BaO}$ & $\mathrm{BeO}$ & $\mathrm{La}_{2} \mathrm{O}_{3}$ & $\mathrm{PbO}$ & $\mathrm{Bi}_{2} \mathrm{O}_{3}$ & \\
\hline $1 \& 22$ & C-1458 & 6.8 & 41. 2 & 52.0 & -.... & -..... & - n. & - . - & -..... & - . & - . & Anhydrous $\mathrm{Al}_{2} \mathrm{O}_{3}$ \\
\hline $2 \ldots$ & $\mathrm{C}-1474$ & 6.8 & 43. 7 & 49.5 & 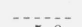 & -..... & -..... & ...... & -..... & ...... & - . - & Do. \\
\hline & $2-51$ & 5. 0 & 41.5 & 48.5 & 5.0 & -..... & ...... & 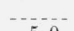 & ...... & ...... & ...... & Hydrated $\mathrm{Al}_{2} \mathrm{O}_{3}$ \\
\hline $4 \ldots \ldots$ & $\mathrm{C}-1540$ & -....- & 49.6 & 45.4 & & -...-- & -..-. & 5.0 & -..... & -..... & - . . & $\begin{array}{l}\mathrm{Hydrated} \quad \mathrm{Al}_{2} \mathrm{O}_{3}, \quad \mathrm{~d} x y \text {-air } \\
\text { treatment. }\end{array}$ \\
\hline $5 \ldots$ & $\mathrm{C}-1532$ & - n & 47.0 & 43.0 & - n- & -..... & 10.0 & -.... & -.... & (n) & - n... & Hydrated $\mathrm{Al}_{2} \mathrm{O}_{3}$ \\
\hline 6 & C-1461 & $\ldots$ & 41. 2 & 42.0 & 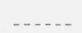 & -- & 16.8 & & & & & Do. \\
\hline $7 \ldots$ & C-1479 & $\ldots$ & 41. 2 & 42.0 & $\ldots$ & ...... & 16.8 & ...... & ...... & $\ldots$ & $\ldots$ & Anhydrous $\mathrm{Al}_{2} \mathrm{O}_{3}$ \\
\hline $8 \ldots \ldots$ & $\begin{array}{l}\mathrm{C}-1528 \\
\mathrm{C}-1464\end{array}$ & ....... & $\begin{array}{l}41.7 \\
38.7\end{array}$ & $\begin{array}{l}38.3 \\
39.5\end{array}$ & -...... & ....... & 20.0 & (....... & ....... & ....... & -..... & Do. \\
\hline $10 \ldots$ & C -1466 & (n..... & 38.7 & 30.0 & (n) & (n) & 21.8 & (n) & 9.5 & (n) & - n & $\begin{array}{l}\text { Hyarated } \mathrm{Al}_{2} \mathrm{O}_{3} \\
\text { Do. }\end{array}$ \\
\hline 11 & $\mathrm{C}-1529$ & ...... & 36.5 & 33.5 & & & 20.0 & 10.0 & & & & Anhydrous $\mathrm{Al}_{2} \mathrm{O}_{3}$ \\
\hline 12 & C-1569 & ...... & 47.0 & 43.0 & ..... & ...... & 5. 0 & 5.0 & $\ldots$ & $\ldots$ & $\ldots$ & Hydrated $\mathrm{Al}_{2} \mathrm{O}_{3}$ \\
\hline $13 \ldots$ & C-1468 & -.... & 41.2 & 42.0 & -..... & -..... & 6.8 & 5.0 & 5.0 & -..... & -..... & Do. \\
\hline 14 & $\mathrm{C}-1478$ & ...... & 41. 2 & 42.0 & ..... & ...... & 6.8 & 5.0 & 5. 0 & (n) & (n) & 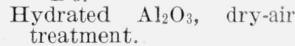 \\
\hline $15 \ldots$ & $\mathrm{C}-1605$ & -.... & 37.2 & 34.2 & -....- & -....- & 14. 3 & 9.5 & -..... & 4. 8 & - n... & Hydrated $\mathrm{Al}_{2} \mathrm{O}_{3}$ \\
\hline 16. & C- -1624 & $\ldots$ & 34.0 & 31. 2 & ....... & -..... & 13.1 & 8.7 & & 13.0 & & Do. \\
\hline 17. & C-1668 & $\ldots$ & 39.1 & 30.9 & - . - & $\ldots$ & 15. 0 & 10.0 & - n... & ..... & 5. 0 & Do. \\
\hline $18 \ldots$ & C-1661 & ...... & 31.3 & 28.7 & ....... & $\ldots \ldots$ & 12.0 & 8.0 & -...... & -...... & 20.0 & Do. \\
\hline 19 & $\mathrm{C}-1660$ & -..... & 31.3 & 28.7 & ...... & ....... & 12.0 & 8.0 & ....... & -..... & 20.0 & 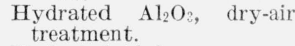 \\
\hline 20 & $\mathrm{C}-1654$ & 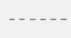 & 28.9 & 26.7 & -- & -...- & 11.1 & 7.4 & - n & - n & 25.9 & Hydrated $\mathrm{Al}_{2} \mathrm{O}_{3}$ \\
\hline 10. & C-1442 & & 28. 2 & 35.6 & ...... & -. & ..... & -..... & - n..... & & 36.2 & Do. \\
\hline 21 & C-1284 & 30.0 & ...... & ...... & ...... & $-10=$ & -..... & -...... & -...... & 70.0 & - & Dry-air treatment \\
\hline $21 \ldots \ldots$ & $\begin{array}{l}\text { C- }-1526 \\
\text { C- } 1434\end{array}$ & ..... & 39.2 & 49.5 & ...... & $\begin{array}{l}42.7 \\
11.3\end{array}$ & ...... & (....... & (....... & 57.3 & - n & Do. \\
\hline $23 \ldots$ & $\mathrm{C}-1534$ & (n) & $\begin{array}{c}09.2 \\
-\ldots .\end{array}$ & $\begin{array}{r}49.5 \\
-\ldots . .\end{array}$ & ....... & $\begin{array}{l}11.3 \\
53.7\end{array}$ & 37.2 & 1.4 & . & 7.7 & -.... & Do. \\
\hline $23 \ldots \ldots$ & $\mathrm{C}-1223$ & 40.0 & ....... & ...... & ....... & ...... & 48.2 & 1.8 & -....... & 10.0 & -...... & \\
\hline
\end{tabular}

mm thick. The batch compositions of glasses C-1458 and C-1474, as well as those for the other glasses reported in the paper, are given in table 1.

The main difficulty, in the preparation of this family of glasses, is their high melting temperature and their tendency toward devitrification when poured in thick slabs. The melting temperature required is about $1,550^{\circ} \mathrm{C}$, measured by means of an optical pyrometer sighted on the surface of the glass. They also show appreciable color, amber to brown, which does not seem to affect their infrared transmittance. This color is probably due to platinum dissolved from the crucibles in which they were melted.

Glasses C-1458 and C-1474, with a silica content of 6.8 percent, have some transmittance out to $6 \mu$ in 2-m.m thicknesses. Previously reported glasses with higher silica content cut off between 5.0 and $5.5 \mu$ [2]. A reduction in silica content also materially increased the transmittance of the glass beyond 3.25 $\mu[3]$. Figure 3 shows the transmittance curve for a low silica eutectic glass, reported by McMurdie and Insley [17], melt 2-51. ${ }^{5}$

The substitution of other oxides for silica was tried, leaving only the $\mathrm{CaO}-\mathrm{Al}_{2} \mathrm{O}_{3}$ group as the glassformer. One in which $\mathrm{BeO}$ was substituted for silica gave a glass of satisfactory quality, free from crystallization. This was glass $\mathrm{C}-1540$, the transmittance curve of which is shown in figure 4 . This glass shows improved transmittance between 2.8 to $3.8 \mu$, but decreased transmittance from 3.8 to $5+\mu$, in comparison with the $\mathrm{CaO}-\mathrm{Al}_{2} \mathrm{O}_{3}-\mathrm{SiO}_{2}$ glasses. This glass was given the dry-air treatment.

${ }^{5}$ In the discussion of the individual glasses, the original melt numbers are used. Consequently, the order has been jumbled to obtain a proper continuity in this paper.
In the $\mathrm{CaO}-\mathrm{Al}_{2} \mathrm{O}_{3}-\mathrm{BaO}$ system, glasses were formed in a wide range of composition: $\mathrm{CaO}, 38$ to 42 percent; $\mathrm{Al}_{2} \mathrm{O}_{3}, 39$ to 47 percent; $\mathrm{BaO}, 10$ to 22 percent. The best glass, as far as ease of production is concerned, is $\mathrm{C}-1532$ (fig. 5), with $\mathrm{C}-1461$ (fig. 6) a close second. To determine the effect of $\mathrm{H}_{2} \mathrm{O}$ in the batch materials, glasses $\mathrm{C}-1479$ and $\mathrm{C}-1528$ (figs. 7 and 8) were made with anhydrous aluminum oxide as the source of alumina; glasses $\mathrm{C}-1461$ and $\mathrm{C}-1464$ (figs. 6 and 9) were made with hydrated alumina. Those made with hydrated alumina show a slightly more prominent absorption band at 2.9 to $3.0 \mu$ than those made with anhydrous alumina.

Glass C-1466 (fig. 10) is of the same composition as glass $\mathrm{C}-1464$ (fig. 9), with the exception of 9.5 percent of $\mathrm{La}_{2} \mathrm{O}_{3}$ in place of $\mathrm{CaO}$. This substitution had practically no effect on the transmittance.

A comparison of figures 5 to 9 shows that the substitution of $\mathrm{BaO}$ for $\mathrm{CaO}$ and $\mathrm{Al}_{2} \mathrm{O}_{3}$ has no effect on the infrared transmittance of the glasses. However, comparison of figure 8 with 11 shows that the substitution of $\mathrm{BeO}$ for $\mathrm{CaO}$ and $\mathrm{Al}_{2} \mathrm{O}_{3}$ substantially decreases the transmittance beyond $4.5 \mu$, acting similarly to $\mathrm{SiO}_{2}$ in this respect, a fact also indicated by figure 12 . It also seems to increase the transmittance at 2.9 to $3.0 \mu$, but less effectively than the dry-air treatment.

Modification of some glasses prepared by Sun [6] gave a five-component glass $\mathrm{CaO}-\mathrm{Al}_{2} \mathrm{O}_{3}-\mathrm{BaO}-\mathrm{BeO}-$ $\mathrm{La}_{2} \mathrm{O}_{3}$ that could be prepared without too much difficulty. Glass C-1468 (fig. 13) was prepared in the usual manner, whereas glass C-1478 (fig. 14) of the same composition was given the dry-air treat- 
ment. Both melts were made with hydrated alumina. Glass C-1478 shows superior transmittance between 2.8 and $4.75 \mu$. Note in figure 13 that the decrease in the 2.9 - to $3.0-\mu$ absorption due to $\mathrm{BeO}$, observed in figures 11 and 12 , does not persist, while the absorption beyond $4.5 \mu$ does persist.

Transmittance curves for glass C-1605, containing 4.8 percent $\mathrm{PbO}$, is shown in figure 15 and for glass $\mathrm{C}-1624$, containing 13.0 percent $\mathrm{PbO}$, in figure 16. The curves for these glasses are quite similar, except that the glass with the larger $\mathrm{PbO}$ content shows a slightly more prominent absorption band at 2.9 to $3.0 \mu$.

In the hope of lowering the melting temperature of the calcium aluminate glasses, four melts containing $\mathrm{Al}_{2} \mathrm{O}_{3}, \mathrm{CaO}, \mathrm{BaO}, \mathrm{BeO}$, and varying amounts of $\mathrm{Bi}_{2} \mathrm{O}_{3}$ (figs. 17, 18, 19, and 20) and one containing only $\mathrm{Al}_{2} \mathrm{O}_{3}, \mathrm{CaO}$, and $\mathrm{Bi}_{2} \mathrm{O}_{3}$ rolass $\mathrm{C}-1442$ in fig. 10 ) were made. The hope of a low melting temperature was, however, a false one. Examination of figures 17, 18 , and 20 shows that the absorption caused by water at $2.9 \mu$ is not affected by the $\mathrm{Bi}_{2} \mathrm{O}_{3}$ content, while figure 19 shows that the dry-air treatment can materially decrease this absorption. A comparison of figures 17 and 20 shows that increasing the $\mathrm{Bi}_{2} \mathrm{O}_{3}$ from 5 to 26 percent, with $\mathrm{BeO}$ present, does not increase the transmittance beyond $4.5 \mu$. Nor does the addition of $\mathrm{Bi}_{2} \mathrm{O}_{3}$ up to 36.2 percent (glass $\mathrm{C}-1442$ ) have any significant effect on the transmittance in comparison with the barium oxide glass C-1464 in the absence of $\mathrm{BeO}$ (figs. 9 and 10). The increased transmittance, beyond $4.5 \mu$ shown in the latter pair of figures, in comparison with figures 11 , and 17 to 20 , is evidently due to the fact that $\mathrm{BeO}$ is absent.

It seems apparent from the representative glasses given in this paper that, although novel compositions for glasses have been found among the calcium aluminates, their application to the transmittance of infrared energy is limited for certain uses because of the high water absorption. This is indicated by the absorption bands at 2.9 and $4.7 \mu$. However, this difficulty can be somewhat overcome by means of the dry-air treatment.

The usefulness of glass for many applications is often determined, not only by transmittance, but also by other physical properties as well. The unusually high value of Young's modulus for one calcium aluminate composition is reported here since it may be of practical, as well as theoretical, interest. Glass C-1461 has a Young's modulus of 1,052 kilobars $(15,230,000 \mathrm{psi})$ at $20^{\circ} \mathrm{C}$. This is in comparison to that for fused silica of 730 kilobars $(10,590,000$ psi) and for most commercial glasses of 540 to 805 kilobars $(7,830,000$ to $11,680,000$ psi) [18]. In table 2, the values for Young's and shear moduli and Poisson's ratio for this glass are given for various temperatures from $20^{\circ}$ to $750^{\circ} \mathrm{C}$.

Coefficients of expansion of five calcium aluminate glasses (C-1461, C-1468, C-1529, C-1532, and $\mathrm{C}-1654)$ varied from $9.0 \times 10^{-6}$ to $11.1 \times 10^{-6} /{ }^{\circ} \mathrm{C}$, with $\mathrm{C}-1654$ giving the lowest and $\mathrm{C}-1461$ the highest value. The deformation points ${ }^{6}$ of these same glasses varied from $671^{\circ}$ to $835^{\circ} \mathrm{C}$, with $\mathrm{C}-1529$ having the lowest, and $\mathrm{C}-1532$ the highest, value.

TABLE 2. Young's and shear moduli and Poisson's ratio versus temperature for calcium aluminate glass $C-1,461$

\begin{tabular}{|c|c|c|c|}
\hline $\begin{array}{c}\text { Temper- } \\
\text { ature }\end{array}$ & $\begin{array}{c}\text { Young's } \\
\text { modulus } \\
(\mathrm{E})\end{array}$ & $\begin{array}{c}\text { Shear } \\
\text { modulus } \\
(\mathrm{G})\end{array}$ & $\begin{array}{c}\text { Poisson's } \\
\text { ratio }\end{array}$ \\
& & & \\
${ }^{\circ} \mathrm{C}$ & Kilobars & & Kilobars \\
20 & 1052 & 408.0 & \\
65 & 1045 & 405.9 & 0.289 \\
110 & 1041 & 403.9 & .287 \\
210 & 1028 & 397.6 & .289 \\
300 & 1017 & 393.5 & .293 \\
& & & .292 \\
410 & 999.5 & 387.1 & .291 \\
500 & 989.1 & 382.8 & .292 \\
600 & 974.7 & 376.7 & .294 \\
700 & 956.0 & 368.8 & .296 \\
730 & 952.4 & 366.5 & .299 \\
750 & 934.0 & 359.8 & .298 \\
& & & \\
& & & \\
& & &
\end{tabular}

\section{Germanate Glasses}

The great advantage of the dry-air treatment to glasses has been shown in a previous paper [3]. Figure 21 compares the transmittance of a lead silicate glass $\mathrm{C}-1284$ with that for the molar equivalent lead germanate glass $\mathrm{C}-1526$. Both were given the dry-air treatment. ${ }^{7}$ Had glass C-1284 not been given the dry-air treatment, its transmittance at 2.9 to $3.0 \mu$ would only have been 30 to 40 percent [3]. Out to $3.6 \mu$, the silicate glass C-1284 has the higher transmittance; beyond $3.6 \mu$ the germanate glass $\mathrm{C}-1526$ has the superior transmittance. The lower transmittance of the germanate glass below $3.6 \mu$ is probably due to its higher index of refraction, hence higher reflectance. Also, the range of transparency in the infrared is increased about $1.2 \mu$ in the case of the germanate glass, in line with the respective vibration frequencies: for $\mathrm{Si}-\mathrm{O}, 1,242.03 \mathrm{~cm}^{-1}(8.05 \mu)$; and for $\mathrm{Ge}-\mathrm{O}, 985.7$ $\mathrm{cm}^{-1}(10.15 \mu)$ [19].

Glass $\mathrm{C}-1,434$ (fig. 22) is the $\mathrm{CaO}-\mathrm{Al}_{2} \mathrm{O}_{3}-\mathrm{GeO}_{2}$ glass equivalent, in mole percent, to $\mathrm{CaO}-\mathrm{Al}_{2} \mathrm{O}_{3}-\mathrm{SiO}_{2}$ glass $\mathrm{C}-1458$ (fig. 1). In this case, the silicate glass C-1434 has slightly higher transmittance out to 4.6 $\mu$. Beyond $4.6 \mu$, the germanate glass $\mathrm{C}-1,434$ is definitely the better.

In figure 23 , glass $\mathrm{C}-1534$, a $\mathrm{BaO}-\mathrm{PbO}-\mathrm{BeO}-\mathrm{GeO}_{2}$ glass, is compared in transmittance with molar equivalent $\mathrm{BaO}-\mathrm{PbO}-\mathrm{BeO}-\mathrm{SiO}_{2}$ glass $\mathrm{C}-1223$. $\mathrm{Al}-$ though glass $\mathrm{C}-1534$ was given the dry-air treatment and glass $\mathrm{C}-1223$ was not, the latter is the better

6“"The temperature observed during the measurement of expansivity by the interferometer method at which viscous flow exactly counteracts thermal expansion. The deformation point generally corresponds to a viscosity in the range sion. The deformation point generally corresponds to a viscosity in the range
from $10^{11}$ to $10^{12}$ poises". Terms relating to glass and glass products, ASTM from $10^{11}$ to $10^{12}$ poises"'.
Designation: C-162-49 $\mathrm{T}$.

Designation: C-162-49 T.
7 About 6 years ago we made 30 double-convex lenses of glass C-1284, $41 / 2$ in. ${ }^{7}$ About 6 years ago we made 30 double-convex lenses of glass C-1284, $41 / 2 \mathrm{in}$.
in diameter and $1 \mathrm{in}$. thick at the center, for the Department of the Navy, Bureau of Aeronautics. As far as we know, they are still giving satisfaction, which speaks well for the permanence of the effect of the dry-air treatment. 
transmitter out to $4.1 \mu$. Glass C-1534 does not have as good transmittance beyond $2.8 \mu$ as glass $\mathrm{C}-1526$, which contains only $\mathrm{PbO}$ and $\mathrm{GeO}_{2}$.

\section{Summary}

Calcium aluminate glasses should find wide use for infrared transmission in applications where their prominent water absorption band at 2.9 to $3.0 \mu$ is not detrimental. Where it is detrimental, its magnitude can be decreased somewhat by means of the dry-air treatment. One of the calcium aluminate glasses had a very high Young's modulus-1,052 kilobars or $15,230,000$ psi. and it may find special applications for this reason. It has been found that $\mathrm{BeO}$ has a detrimental effect on the transmittance of calcium aluminate glasses beyond $4.5 \mu$.

The dry-air treatment of a lead germanate glass melt produced one of the best oxide glasses for the transmittance of infrared energy to come to our attention, especially for wavelengths beyond $3.6 \mu$. However, the high cost and short supply of $\mathrm{GeO}_{2}$ will limit application of germanate glasses.

To our present knowledge, the transmittance of oxide glasses for infrared energy seems limited to about $6 \mu$ for $2-\mathrm{mm}$ thicknesses. Since it has been found that the use of higher atomic weight elements in general extends the region of infrared transmittance, the best possibility of increasing this region is by replacing oxygen by heavier elements such as sulfur, selenium, etc.

The authors are indebted to Marshall Anderson and Nicolo Acquista, of the Radiometry Section, for supplying the data on the transmittance of these glasses.

\section{References}

[1] J. M. Florence, F. W. Glaze, C. H. Hahner, and R. Stair, Transmittance of near-infrared energy by binary glasses, J. Am. Ceramic Soc. 30, 328 (1948); J. Research NBS 41, 623 (1948) RP1945.

[2] J. M. Florence, C. C. Allshouse, F. W. Glaze, and C. H. Hahner, The absorption of near-infrared energy by certain glasses, J. Research NBS 45, 121 (1950) RP2118.

[3] J. M. Florence, F. W. Glaze, and M. H. Black, Trans. mission of near-infrared energy by some two- and three-component glasses, J. Research NBS 50, 187 (1953) R P2408.

[4] G. Heyne, The preparation and properties of some beryllium flouride glasses, Angew, Chem. 46, 473 (1933)

[5] E. S. Shepherd, G. A. Rankin, and F. E. Wright, The binary systems of alumina with silica, lime, and magnesia, Am. J. Sci. [4] 28, 293 (1909).

[6] W. Büssem and A. Eitel, The structure of pentacalcium trialuminate, Z. Krist. 95, 175 (1936).

[7] J. M. Stevels, The physical properties of glass in relation to its structure, J. Soc. Glass Tech. 30, 31 T (1946).

[8] Hurd W. Safford and Alexander Silverman, Aluminasilica relationship in glass, J. Am. Ceramic Soc. 30, 203 (1947)

[9] K. Sun, Glass-forming substances, Glass Ind. 27, 552 (1946).
[10] K. Sun, Aluminate glasses, Glass Ind. 30, 199 (1949).

[11] K. Sun, A note on aluminate glass, Glass Ind. 32, 82 (1951).

[12] J. E. Stanworth, K. Sun, More about aluminate glasses, Glass Ind. 32, 296 (1951).

[13] J. E. Stanworth, On the structure of glass, J. Soc. Glass Tech. 32, $154 \mathrm{~T}$ (1948).

[14] W. A. Weyl, Coloured glasses, J. Soc. Glass Tech. 27, 133 (1943).

[15] G. A. Rankin and F. E. Wright, The ternary system: $\mathrm{CaO}-\mathrm{Al}_{2} \mathrm{O}_{3}-\mathrm{SiO}_{2}, \mathrm{Am}$. J. Sci. [4] 39, 52 (1915).

[16] J. W. Greig, Immiscibility of silicate melts, Am. J. Sci. [5] 13, 41 (1927)

[17] H. F. Mc Murdie and H. Insley, Studies on the quaternary system $\mathrm{CaO}-\mathrm{MgO}-2 \mathrm{CaO} . \mathrm{SiO}_{2}-5 \mathrm{CaO} .3 \mathrm{Al}_{2} \mathrm{O}_{3}$, J. Research NBS 16, 467 (1936) R P884.

[18] Sam Spinner, Elastic moduli of glasses by a dynamic method, J. Am. Ceramic Soc. 3\%, 229 (1954).

[19] Gerhard Herzberg, Molecular spectra and molecular structure I. Spectra of diatomic molecules, 2nd ed., table 39 (D. Van Nostrand Co., Inc., New York, N. Y., 1951).

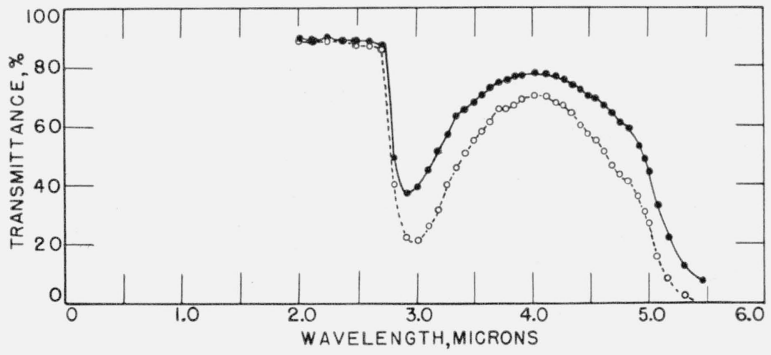

Figure 1. Infrared transmittances of $\mathrm{CaO}-\mathrm{Al}_{2} \mathrm{O}_{3}-\mathrm{SiO}_{2}$ glass $C-1,458$.

$\mathrm{T}=2.18 \mathrm{~mm} ; \mathrm{O}, \mathrm{T}=4.10 \mathrm{~mm}$

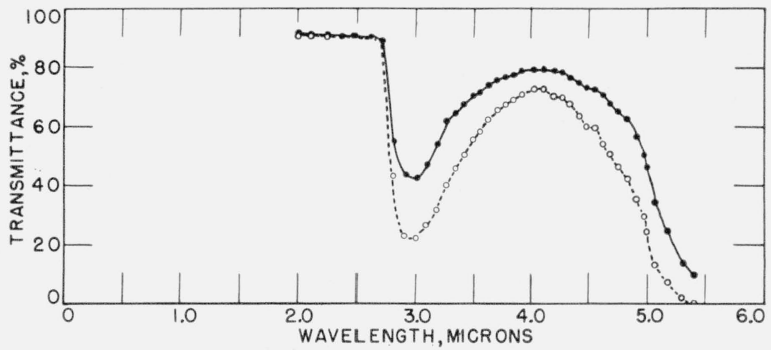

Figure 2. Infrared transmittances of $\mathrm{CaO}-\mathrm{Al}_{2} \mathrm{O}_{3}-\mathrm{SiO}_{2}$ glass $C-1,474$.

$\mathrm{T}=2.02 \mathrm{~mm} ; \mathrm{O}, \mathrm{T}=4.16 \mathrm{~mm}$

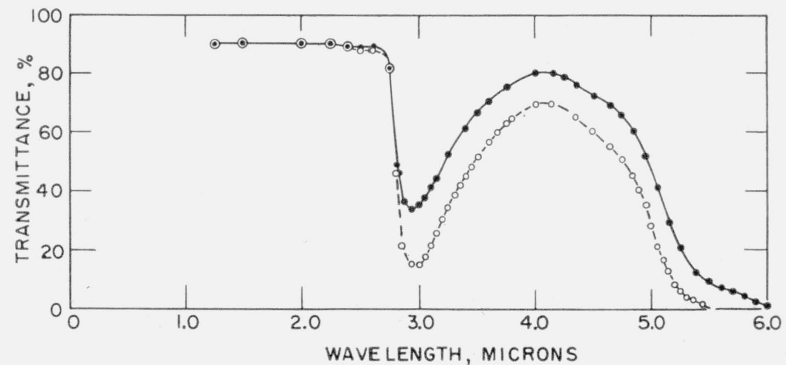

Figure 3. Infrared transmittances of $\mathrm{CaO}-\mathrm{Al}_{2} \mathrm{O}_{3}-\mathrm{MgO}$ $\mathrm{SiO}_{2}$ glass 2-51

$\mathrm{T}=2.00 \mathrm{~mm} ; \cap . \mathrm{T}=3.96 \mathrm{~mm}$ 


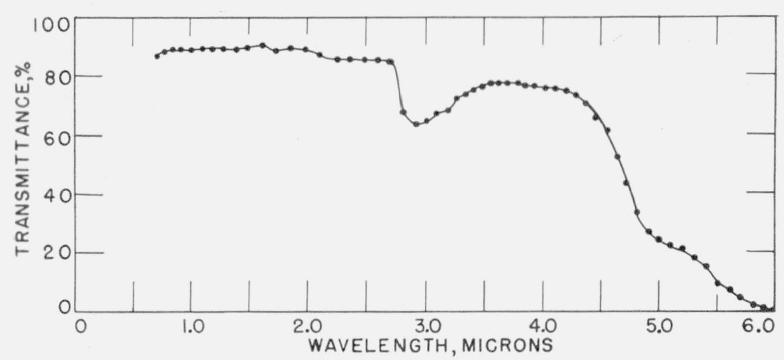

Figure 4. Infrared transmittances of $\mathrm{CaO}-\mathrm{Al}_{2} \mathrm{O}_{3}-\mathrm{BeO}$ glass $C-1,540$.

This glass was given the dry-air treatment. $\mathrm{T}=2.02 \mathrm{~mm}$

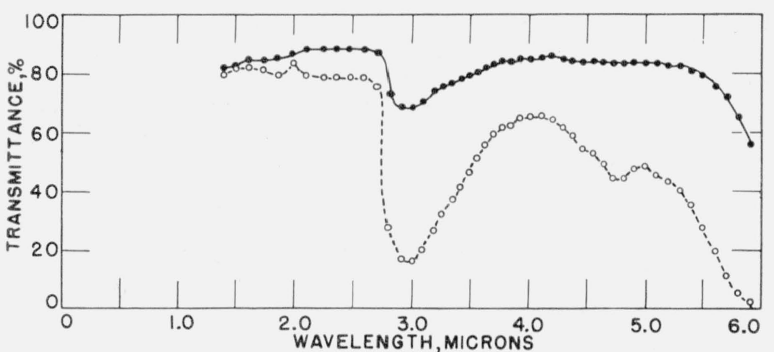

FIGURE 5. Infrared transmittances of $\mathrm{CaO}-\mathrm{Al}_{2} \mathrm{O}_{3}-\mathrm{BaO}$ glass $C-1,532$

, $\mathrm{T}=0.39 \mathrm{~mm} ; \bigcirc, \mathrm{T}=3.56 \mathrm{~mm}$.

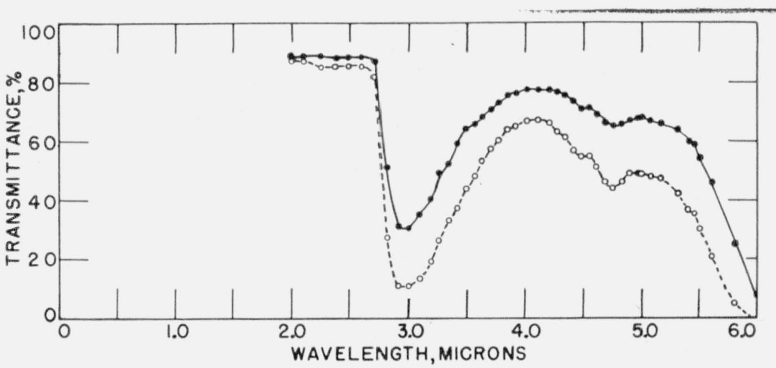

Figure 6. Infrared transmittances of $\mathrm{CaO}-\mathrm{Al}_{2} \mathrm{O}_{3}-\mathrm{BaO}$ glass $\mathrm{C}-1,461$ (hydrated $\mathrm{Al}_{2} \mathrm{O}_{3}$ ).

- $\mathrm{T}=1.72 \mathrm{~mm} ; \mathrm{O}, \mathrm{T}=3.50 \mathrm{~mm}$.

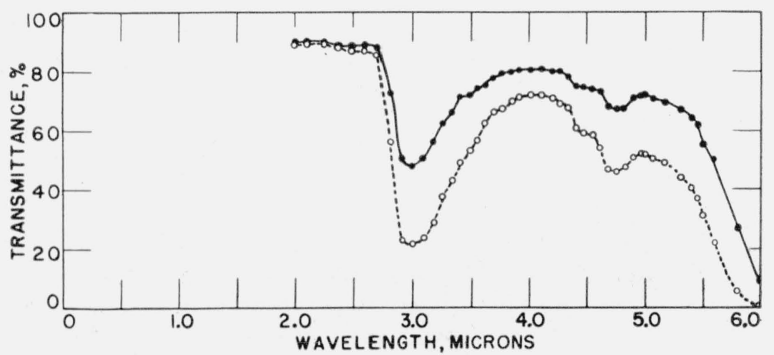

Figure 7. Infrared transmittances of $\mathrm{CaO}-\mathrm{Al}_{2} \mathrm{O}_{3}-\mathrm{BaO}$ glass C-1,479 (anhydrous $\mathrm{Al}_{2} \mathrm{O}_{3}$ ).

- $\mathrm{T}=1.71 \mathrm{~mm} ; \bigcirc, \mathrm{T}=3.99 \mathrm{~mm}$.

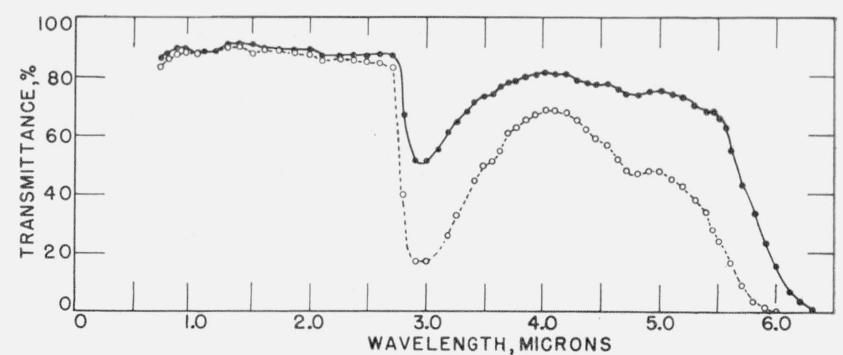

FIGURE 8. Infrared transmittances of $\mathrm{CaO}-\mathrm{Al}_{2} \mathrm{O}_{3}-\mathrm{BaO}$ glass C-1,528.

- $\mathrm{T}=1.11 \mathrm{~mm} ; \mathrm{O}, \mathrm{T}=3.81 \mathrm{~mm}$.

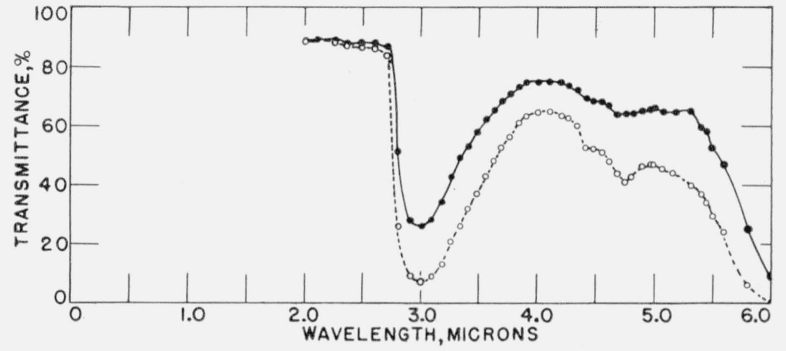

Figure 9. Infrared transmittances of $\mathrm{CaO}-\mathrm{Al}_{2} \mathrm{O}_{3}-\mathrm{BaO}$ glass C-1,464.

$\mathrm{T}=1.78 \mathrm{~mm} ; \bigcirc, \mathrm{T}=3.81 \mathrm{~mm}$

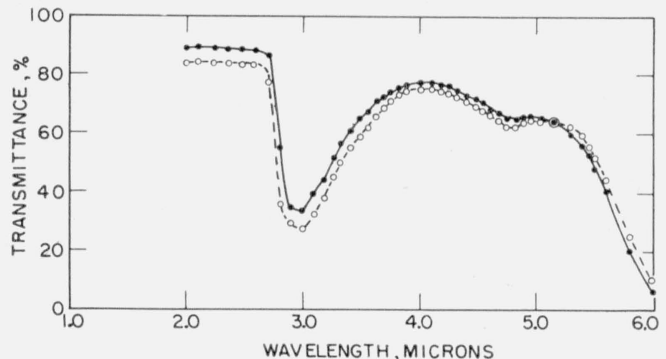

Figure 10. Infrared transmittances of $\mathrm{CaO}-\mathrm{Al}_{2} \mathrm{O}_{3}-\mathrm{BaO}$ $\mathrm{La}_{2} \mathrm{O}_{3}$ glass $\mathrm{C}-1,466$ and $\mathrm{CaO}-\mathrm{Al}_{2} \mathrm{O}_{3}-\mathrm{Bi}_{2} \mathrm{O}_{3}$ glass $C-1442$.

-, Glass $\mathrm{C}-1,466, \mathrm{~T}=1.98 \mathrm{~mm}$; $\bigcirc$, Glass $\mathrm{C}-1,442, \mathrm{~T}=1.82 \mathrm{~mm}$.

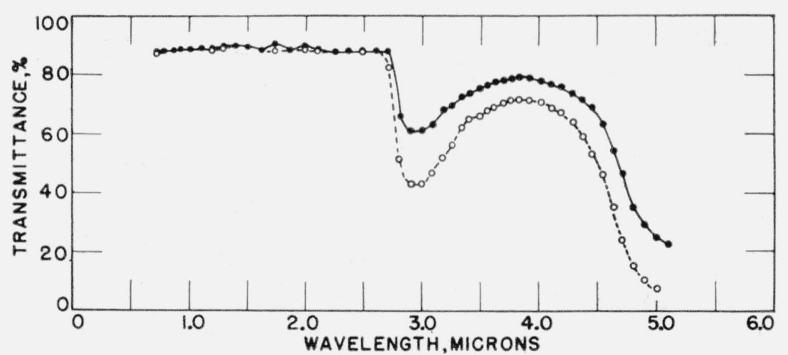

Figure 11. Infrared transmittances of $\mathrm{CaO}-\mathrm{Al}_{2} \mathrm{O}_{3}-\mathrm{BaO}-\mathrm{BeO}$ glass $C-1,529$.

- $\mathrm{T}=1.07 \mathrm{~mm} ; \mathrm{O}, \mathrm{T}=2.04 \mathrm{~mm}$. 


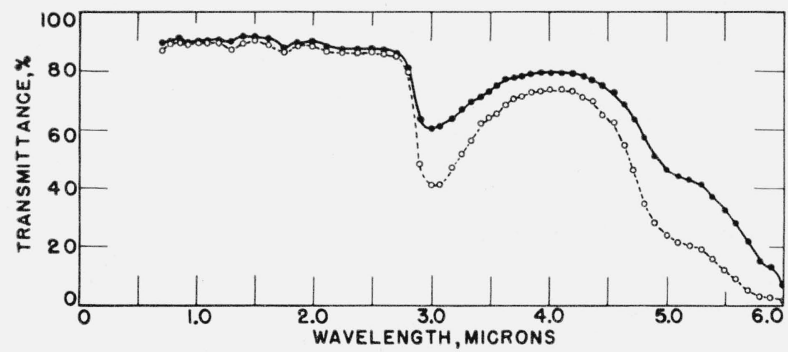

Figure 12. Infrared transmittances of $\mathrm{CaO}-\mathrm{Al}_{2} \mathrm{O}_{3}-\mathrm{BaO}-\mathrm{BeO}$ glass $C-1,569$.

$\mathrm{T}=0.95 \mathrm{~mm} ; \bigcirc, \mathrm{T}=1.96 \mathrm{~mm}$.

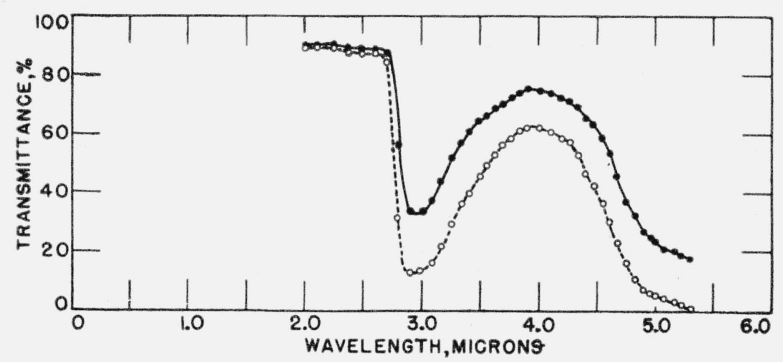

Figure 13. Infrared transmittances of $\mathrm{CaO}-\mathrm{Al}_{2} \mathrm{O}_{3}-\mathrm{BaO}-$ $\mathrm{BeO}-\mathrm{La}_{2} \mathrm{O}_{3}$ glass $\mathrm{C}-1,468$.

$\mathrm{T}=2.04 \mathrm{~mm} ; \bigcirc, \mathrm{T}=4.16 \mathrm{~mm}$

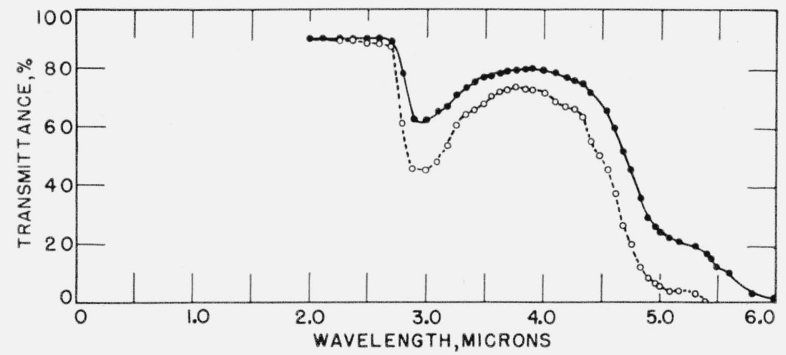

FiguRE 14. Infrared transmittances of glass $C-1,478$ (glass $C-1,468$ given the dry-air treatment).

$\mathrm{T}=2.05 \mathrm{~mm} ; \bigcirc, \mathrm{T}=4.16 \mathrm{~mm}$.

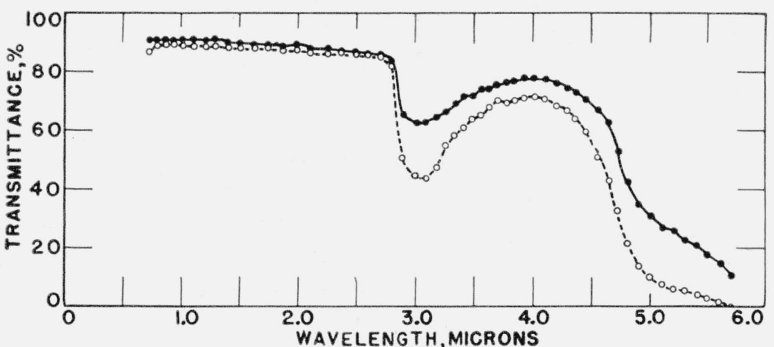

Figure 15. Infrared transmittances of $\mathrm{CaO}-\mathrm{Al}_{2} \mathrm{O}_{3}-\mathrm{BaO}$ $\mathrm{BeO}-\mathrm{PbO}$ glass $C-1,605$

$\mathrm{T}=0.97 \mathrm{~mm} ; \bigcirc, \mathrm{T}=1.98 \mathrm{~mm}$.

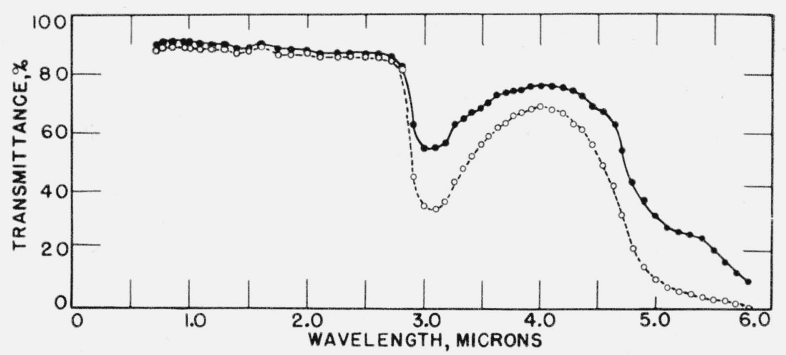

Figure 16. Infrared transmittances of $\mathrm{CaO}-\mathrm{Al}_{2} \mathrm{O}_{3}-\mathrm{BaO}$ $\mathrm{BeO}-\mathrm{PbO}$ glass $\mathrm{C}-1,624$.

- $\mathrm{T}=0.91 \mathrm{~mm} ; \bigcirc, \mathrm{T}=1.97 \mathrm{~mm}$

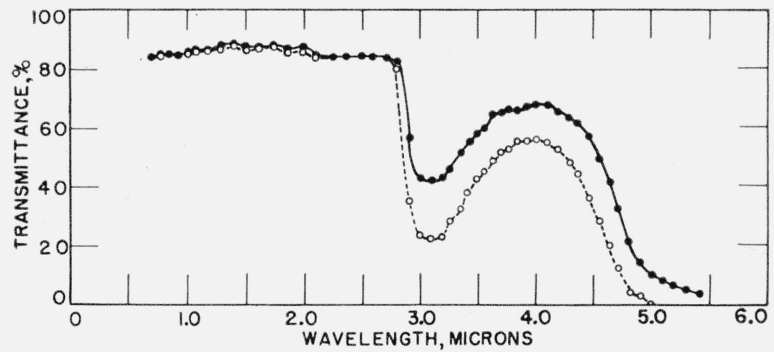

Figure 17. Infrared transmittances of $\mathrm{CaO}-\mathrm{Al}_{2} \mathrm{O}_{3}-\mathrm{BaO}-$ $\mathrm{BeO}-\mathrm{Bi}_{2} \mathrm{O}_{3}$ glass $\mathrm{C}-1,666^{\circ}$.

$\mathrm{T}=1.96 \mathrm{~mm} ; \bigcirc, \mathrm{T}=3.98 \mathrm{~mm}$.

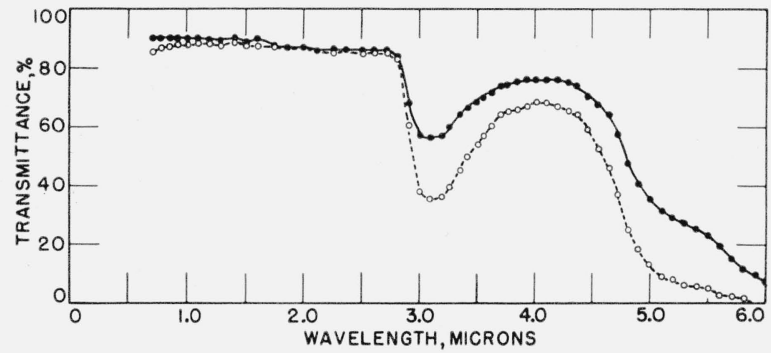

Figure 18. Infrared transmittances of $\mathrm{CaO}-\mathrm{Al}_{2} \mathrm{O}_{3}-\mathrm{BaO}$ $\mathrm{BeO}-\mathrm{Bi}_{2} \mathrm{O}_{3}$ glass $\mathrm{C}-1,661$.

$\mathrm{T}=0.90 \mathrm{~mm} ; \bigcirc, \mathrm{T}=1.97 \mathrm{~mm}$.

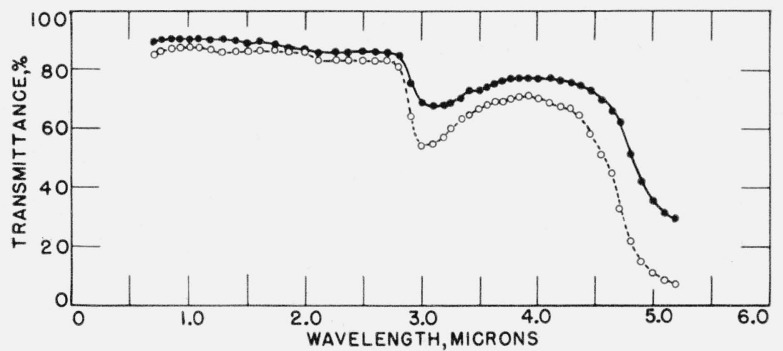

FiguRE 19. Infrared transmittances of glass $C-1,660$ (glass $C-1,661$ given the dry-air treatment).

$\mathrm{T}=0.90 \mathrm{~mm} ; \bigcirc, \mathrm{T}=2.01 \mathrm{~mm}$. 


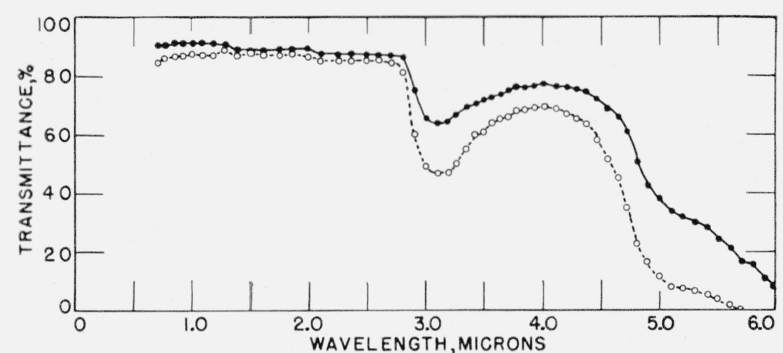

Figure 20. Infrared transmittances of $\mathrm{CaO}-\mathrm{Al}_{2} \mathrm{O}_{3}-\mathrm{BaO}$ $\mathrm{BeO}-\mathrm{Bi}_{2} \mathrm{O}_{3}$ glass $\mathrm{C}-1,6 \dot{5} 4$.

$\mathrm{T}=0.88 \mathrm{~mm} ; \bigcirc, \mathrm{T}=2.02 \mathrm{~mm}$

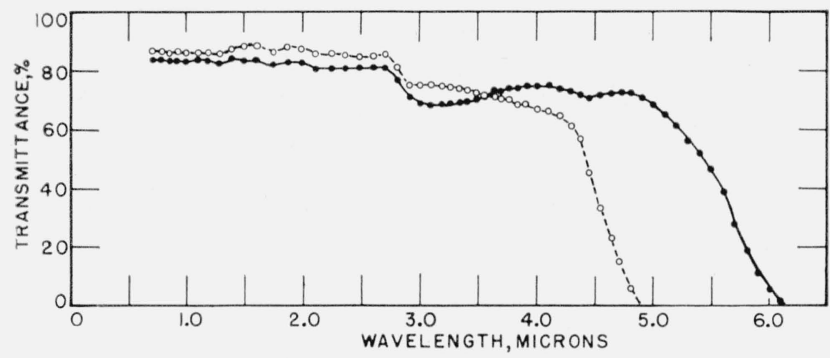

Figure 21. Infrared transmittances of $\mathrm{PbO}-\mathrm{SiO}_{2}$ glass $C$ 1,284 and the equivalent $\mathrm{PbO}-\mathrm{GeO}_{2}$ glass $C-1,526$, both given the dry-air treatment.

-, Glass $\mathrm{C}-1,526, \mathrm{~T}=2.07 \mathrm{~mm} ; \mathrm{O}$, Glass $\mathrm{C}-1,284, \mathrm{~T}=1.90 \mathrm{~mm}$.

Washington, June 22, 1955.

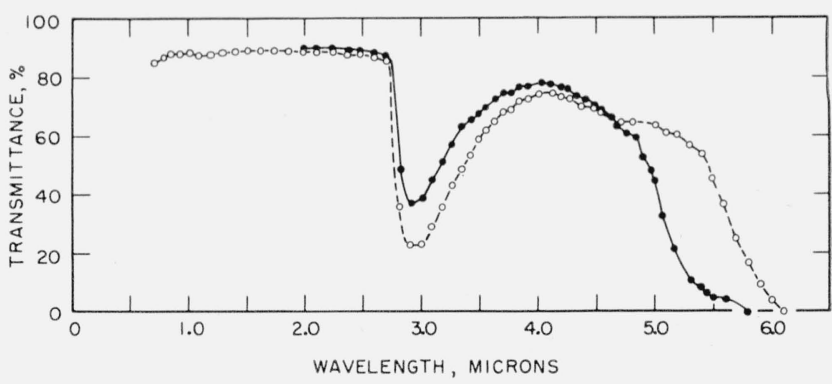

Figure 22. Infrared transmittances of $\mathrm{CaO}-\mathrm{Al}_{2} \mathrm{O}_{3}-\mathrm{SiO}_{2}$ glass $C-1,458$ and the equivalent $\mathrm{CaO}-\mathrm{Al}_{2} \mathrm{O}_{3}-\mathrm{GeO}_{2}$ glass $C-1,434$.

, Glass $\mathrm{C}-1,458, \mathrm{~T}=2.18 \mathrm{~mm} ; \boldsymbol{\bullet}$, Glass $\mathrm{C}-1,434, \mathrm{~T}=2.00 \mathrm{~mm}$.

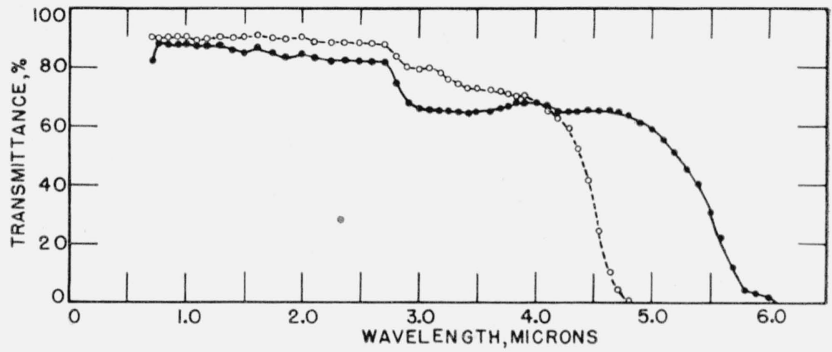

Figure 23. Infrared transmittances of $\mathrm{BaO}-\mathrm{PbO}-\mathrm{BeO}-\mathrm{SiO}_{2}$ glass $C-1,223$ and the equivalent $\mathrm{GeO}_{2}$ glass $C-1,53 \%$, latter with dry-air treatment.

, Glass $\mathrm{C}-1.223, \mathrm{~T}=1.96 \mathrm{~mm} ; \bullet$. Glass $\mathrm{C}-1.534 . \mathrm{T}=1.75 \mathrm{~mm}$. 